\title{
The Histaminergic Mechanism of Neurotensin-induced Glucagon Release from Isolated Rat Pancreatic Islets
}

\author{
Takeharu ITATSU ${ }^{1}$, Atsumi ShibATA ${ }^{2}$ and Mitsuo UKAI $^{3}$ \\ ${ }^{1}$ Department of Internal Medicine, Nagoya Second Red Cross Hospital, \\ ${ }^{2}$ Department of Internal Medicine, Nagoya East City Hospital, \\ ${ }^{3}$ Institute of Cermfree Life Research, Nagoya University \\ School of Medicine, Nagoya, Japan
}

\begin{abstract}
Isolated rat pancreatic islets were preincubated in a medium with $16.7 \mathrm{mM}$ glucose and incubated with $5.5 \mathrm{~mm}$ glucose. Both histamine $(100 \mu \mathrm{M})$ and neurotensin $(100 \mathrm{nM})$ stimulated glucagon release from the isolated islets, but not insulin release. The stimulation of glucagon release occurred in the presence of 10 and $100 \mathrm{nM}$ neurotensin, while the release of insulin was inhibited in the presence of 1 and $10 \mathrm{nM}$ neurotensin. The neurotensin-induced glucagon release was completely inhibited by $1 \mathrm{~mm}$ metiamide, an histamine $\mathrm{H}_{2}$-receptor antagonist, added to the incubation medium and not inhibited by $1 \mathrm{~mm}$ diphenhydramine, an histamine $\mathrm{H}_{1}$-receptor antagonist.

The results indicate that the histaminergic mechanism, including the $\mathrm{H}_{2}$-receptor system, may be involved in neurotensin-induced glucagon release from the endocrine pancreas.
\end{abstract}

Neurotensin is a tridecapeptide originally isolated from bovine hypothalamus (Carraway et al., 1973) and from bovine small intestine (Carraway et al., 1976; Kitabgi et al., 1976). This peptide has been shown to induce hyperglycemia (Brown et al., 1976; Carraway et al., 1976; Ukai et al., 1976; Nagai et al., 1976; Sasaki et al., 1980), in association with low insulin and high glucagon levels in systemic plasma of rats (Brown et al., 1976) and with high insulin and high glucagon levels in the portal vein plasma (Ukai et al., 1977) or in the pancreatic vein plasma (Kaneto et al., 1978) of dogs.

There are in vitro studies indicating the direct action of neurotensin on isolated rat pancreatic islets to release glucagon (Moltz et al., 1977; Shibata et al., 1978; Dolais-Kitabgi et al., 1979; Shibata et al., 1980) and somatostatin (Dolais-Kitabgi et

Received June 3, 1981. al., 1979). Its effect on insulin release has been variously reported as inhibitory (Moltz et al., 1977) and stimulatory (Dolais-Kitabgi et al., 1979). Although the mechanism of the neurotensin-induced release of pancreatic hormones is not fully understood, the histaminergic mechanism has been thought to be involved in neurotensin-induced hyperglucagonemia, based on in vivo studies in rats (Brown et al., 1976; Nagai et al., 1978).

In the present study, we investigated such an histaminergic mechanism of neurotensin-induced glucagon release, using the isolated pancreatic islet system of rat. A part of this study has been reported before (Ukai et al. 1980).

\section{Materials and Methods}

Isolation and incubation of pancreatic islets Female Sprague-Dawley rats ranging in weight 
Table 1. Effect of Arginine, Neurotensin and Histamine on Glucagon aud Insulin Release from Isolated Pancreatic Islets of Rats.

\begin{tabular}{lrcc}
\hline \multicolumn{1}{c}{ Group } & & $\begin{array}{c}\text { Glucagon Release } \\
(\mathrm{pg} / \text { islet/30 min })\end{array}$ & $\begin{array}{c}\text { Insulin Release } \\
(\mu \mathrm{U} / \text { islet } / 30 \mathrm{~min})\end{array}$ \\
\hline Control & $(20)$ & $66.1 \pm 4.8$ & $13.2 \pm 0.7$ \\
Arginine & $20 \mathrm{mM}(4)$ & $247.9 \pm 43.0^{*}$ & $25.9 \pm 1.4^{*}$ \\
Neurotensin $100 \mathrm{nM}(\mathrm{y})$ & $127.5 \pm 12.7^{*}$ & $16.4 \pm 1.0$ \\
Histamine $100 \mu \mathrm{M}$ & $(4)$ & $119.5 \pm 10.0^{*}$ & $10.7 \pm 0.7$ \\
\hline
\end{tabular}

Values are slown as the mean \pm SE. Numbers of experiments are shown in parentheses. Significant difference vs. controls is indicated by $*(p<0.01)$.

from 150 to $250 \mathrm{~g}$ were given free access to food and water before the experiments. Under intraperitoneal anesthesia with Nembmtal, laparotomy was performed. Pancreatic islets were isolated using the collagenase technique of Lacy and Kostianovsky (1967). Ten islets in each plastic microbeaker were preincubated for $60 \mathrm{~min}$ in $3 \mathrm{ml}$ of Krebs-Ringer bicarbonate buffer ( $\mathrm{pH} 7.4$ ) containing $16.7 \mathrm{mM}$ glucose and incubated for $30 \mathrm{~min}$ in $3 \mathrm{ml}$ of KrebsRinger bicarbonate buffer containing $5.5 \mathrm{~mm}$ glucose with or without various test substances, at $37^{\circ} \mathrm{C}$ in an atmosphere of $\mathrm{O}_{2}-\mathrm{CO}_{2}(95: 5, \mathrm{vol} / \mathrm{vol})$. The microbeakers were shaken at 55 cycles per min throughout the preincubation and incubation periods.

Following incubation, $0.4 \mathrm{~m} l$ of the medium solution was collected into tubes containing $1000 \mathrm{KIU}$ of aprotinin (gift from Bayer Company) and $2.4 \mathrm{mg}$ of EDTA-2Na to prevent the degradation of glucagon and insulin. The samples were immediately frozen and kept at $-20^{\circ} \mathrm{C}$ until assay. Immunoreactive glucagon (IRG) was measured by the dextran-coated charcoal method using 30-K antibody (Böttger et al., 1973). Porcine glucagon (gift from Eli Lilly and Company) was used as the standard. Immunoreactive insulin (IRI) was measured by the solid phase method (Wide and Porath, 1966).

Neurotensin (Protein Research Foundation), diphenhydramine-HCI as an histamine $\mathrm{H}_{1}$-receptor antagonist (Sigma Chemical Company), histamine-HCI and L-arginine-HCI (Nagoya Katayama Chemical Company) were obtained commercially. Metiamide as an histamine $\mathrm{H}_{2}$-receptor antagonist was donated by the Smith, Kline \& French Laboratories.

\section{Analysis}

Data were analyzed by Student's $t$-test, the criterion for significance being $\mathrm{p}>0.05$.

\section{Results}

In our in vitro system, L-arginine (20 $\mathrm{mM})$ stimulated the release of IRG and
IRI from isolated pancreatic islets, values being significantly different from those of the control. Both histamine $(100 \mu \mathrm{M})$ and neurotensin (100 nM) stimulated IRG release without a significant effect on IRI release (Table 1).

The rate of IRG Release (pg/islet/30 min) from isolated islets was $68.9 \pm 2.8$ (mean \pm $\mathrm{SE}$ ) in the presence of $10 \mathrm{nM}$ neurotensin and $118.7 \pm 10.2$ in that of $100 \mathrm{~nm}$ neurotensin (Fig. 1), significantly higher than the control value $(52.8 \pm 2.2)$. On the other hand, in the presence of $1 \mathrm{~nm}$ and $10 \mathrm{~nm}$ neurotensin the rate of IRI release $(\mu \mathrm{U} /$ islet $/$ $30 \mathrm{~min})$ was $10.6 \pm 0.5$ and $11.8 \pm 0.4$, respectively, significantly lower than the control value $(17.3 \pm 0.9)$ and that of $100 \mathrm{~nm}$ neurotensin $(17.2 \pm 0.8)$.

As shown in Fig. 2, neurotensin-induced IRG release was completely blocked by 1 mM metiamide $(51.0 \pm 5.8)$, but not by $1 \mathrm{~mm}$ diphenhydramine $(140.8 \pm 8.3)$. Neither diphenhydramine nor metiamide significantly affected the IRI release in the presence of $100 \mathrm{~nm}$ neurotensin.

\section{Discussion}

The present in vitro study has demonstrated the stimulatory effects of neurotensin and histamine on pancreatic glucagon release in rats. This is consistent with the previous in vivo studies which showed neurotensin-induced hyperglucagonemia in rats (Brown et al., 1976) and dogs (Ukai 


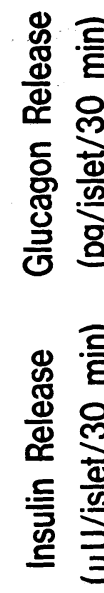

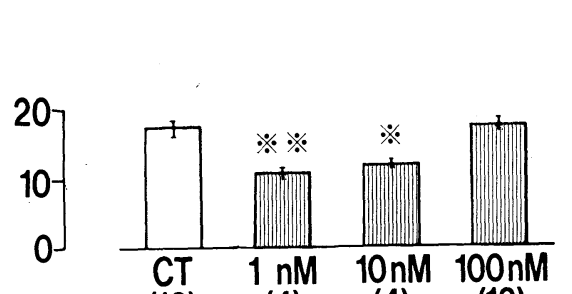

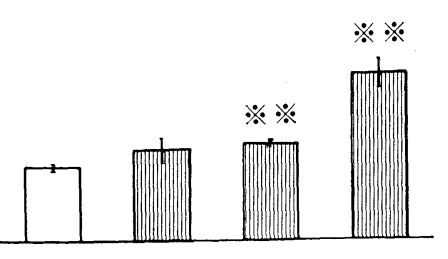

(16)

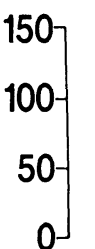

(4)

NT

(13)

Fig. 1. Effect of neurotensin (NT) in the concentrations of 1,10 and $100 \mathrm{~nm}$ on glucagon release and insulin release from isolated islets. Values are shown as the mean \pm SE. Numbers of experiments are shown in parentheses. Significant difference vs. controls (CT) is indicated by one $(\mathrm{p}<0.05)$ and two asterisks $(\mathrm{p}<0.01)$.

et al., 1976). However, as we reported previously (Shibata et al., 1978; 1980), the effect of neurotensin on glucagon release depends upon the concentration of glucose in the incubation medium, being rather inhibitory in a low glucose concentration $(1.67 \mathrm{~mm})$ and most stimulatory in a high glucose concentration $(16.7 \mathrm{~mm})$. This is inconsistent with the results obtained by Dolais-Kitabgi et al. (1979), which showed the inhibitory effect of neurotensin with the high concentration of glucose or arginine and the stimulatory effect with the low concentration $(3 \mathrm{~mm})$ of glucose on glucagon release from isolated rat islets. The fact that when the concentrations was less than $100 \mathrm{~nm}$, neurotensin suppressed insulin release from the isolated islets (Fig. 1), may be compatible with the results of Moltz et al., (1977) using 3- to 4-day-old Wistar rats, but inconsistent with those of Dolais-Kitabgi et al., (1979), using adult Sprague-Dawley rats. Although it is difficult to explain the dis-
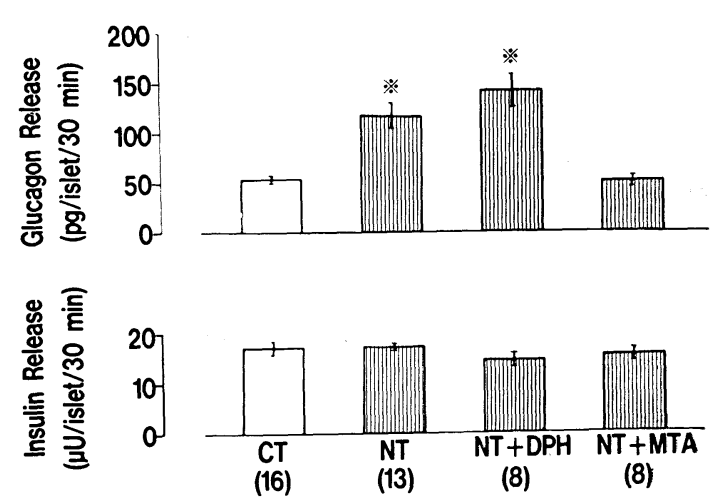

Fig. 2. Effects of diphenhydramine-HCI (DPH) and metiamide (MTA) on neurotensin (NT) -induced glucagon release from isolated islets. The concentrations of NT, DPH and MTA in the media were $100 \mathrm{nM}, 1 \mathrm{~mm}$ and $1 \mathrm{~mm}$, respectively. Values are shown as the mean \pm SE. Numbers of expriments are shown in parentheses. Significant difference vs. controls (CT) is indicated by an asterisk $(\mathrm{p}<0.01)$.

crepancys in the results obtained by various investigators, we tentatively assume that the high concentration of medium glucagon caused by neurotensin might stimulate insulin release. If this assumption is correct, no inhibition of insulin release by $100 \mathrm{~nm}$ neurotensin might be explained by this mechanism. It is likely that the effect of neurotensin on the release of pancreatic hormones from the isolated islets may differ, depending upon not only the concentration of glucose, insulin, glucagon and somatostatin in the medium but also the age or the physiological condition of rats used in the experimedts. This concept may partly account for a seemingly dual effect of neurotensin on the release of pancreatic hormones obtained in our in vitro system.

A good deal of similarity between the biological properties of neurotensin and those of histamine in both the central and peripheral nervous systems has been shown from various aspects such as prolactin 
release (Livertun et al., 1976; Rivier et al., 1977), hypothermia (Bissette et al., 1976; Shaw, 1971; Green et al., 1976), hypotension and increased capillary permeability (Carraway et al., 1973 ; Beaven. 1976). Both neurotensin and histamine are known to be present in high concentrations in the hypothalamus and the gastrointestinal tract (Carraway et al., 1976; Kitabgi et al., 1976; Green, 1964; Beaven, 1976). Neurotensin or its specific receptors may be widely distributed, possibly even in the pancreas, and may regulate the secretions of insulin, glucagon and somatostatin by functioning as a neurotransmitter or as a local modulatory factor. It was found in the present study that histamine stimulated glucagon release from the isolated islets of rats (Table 1 ), and this is consistent with the results reported by Pontiroli et al. (1979). In addition, neurotensin-induced glucagon release was completely blocked by metiamide, an $\mathrm{H}_{2}$-receptor antagonist, but rather stimulated by diphenhydramine, an $\mathrm{H}_{1}$-receptor antagonist, which had been reported before (Itatsu et al., 1979), being inconsistent with the results of Brown et al. (1976) and partially compatible with the those of Nagai et al. (1978). According to the present data on $30 \mathrm{~min}$ incubation, diphenhydramine was likely to accelerate neurotensin-induced glucagon release. One explanation is that the affinity of the $\mathrm{H}_{2}$-receptors for neurotensin might be relatively increased by blocking the $\mathrm{H}_{1}$-receptors. Another is that the incubation time for $30 \mathrm{~min}$ might be too short for the $\mathrm{H}_{1}$-receptor antagonist to exert a full effect on the pancreatic A-cell response to neurotensin, The latter concept seems to be supported by the study of Bruce et al. (1979), in which the antral-strip response to histamine was stimulated during initial exposure but inhibited on longer exposure to diphenhydramine, while the response was always inhibited by cimetidine, an $\mathbf{H}_{2}$-receptor antagonist. Data obtained in the present study may be interpreted, at least, as indicating that the $\mathrm{H}_{2}$-receptors may be involved in mediating the neurotensin-induced glucagon release.

To elucidate the mechanism by which the $\mathrm{H}_{2}$-receptor antagonist suppresses the neurotensin-induced glucagon release in the present system, possibilities such as the presence of competitive antagonism for the neurotensin receptor (Lazarus et al., 1977; Rioux et al., 1980) and indirect inhibition of the messengers or mediators through the $\mathrm{H}_{2}$-receptors (Dismukes et al., 1975; Feldman and Richardson, 1978; Rioux et al., 1980) must be taken into consideration.

\section{Acknowledgements}

The authors wish to express their thanks to Miss Keiko Okada, Mrs. Michiko Kishi and Miss Fumiko Maeda for their excellent technical assisstance. This work was supported in part by a grant f.om the Imanaga Medical Research Foundation, Nagoya.

\section{References}

Beaven, M. A. (1976). Histamine. N. Engl. J. Med. 294, 30-36.

Bissette, G., C. B. Nemeroff, P. T. Loosen, A. J. Jr. Prange and M. A. Lipton (1976). Hypothermia and intolerance to cold induced by intracisternal administration of the hypothermia peptide neurotensin. Nature 262, 607-609.

Böttger, I., R. Dobbs, G. R. Faloona and R. H. Unger (1973). The effects of triglyceride absorption upon glucagon, insulin and gut glucagon-like immunoreactivity. J. Clin. Invest. 52, 2532-2541.

Brown, M. and W. Vale (1976). Effect of neurotensin and substance $\mathbf{P}$ on plasma insulin, glucagon and glucose levels. Endocrinology 98, 819-822.

Brown, M., J. Villarreal and W. Vale (1976). Neurotensin and substance P; Effects on plasma insulin and glucagon levels. Metabolism 25, 1459-1461.

Bruce, L. A., F. M. Behsudi and C. P. Fawcett (1979). Histaminergic involvement in thyrotropinreleasing hormone stimulation of antral tissue in the rat. Gastroenterology 76, 908-912.

Carraway, R. E. and S. E. Leeman (1973). The isolation of a new hypotensive peptide, neurotensin from bovine hypothalami. J. Biol. Chem. 248, 6854-6861.

Carraway, R. E., L. Demers and S. E. Leeman (1976). 
Hypergycemic effects of neurotensin, a hypothalamic peptide. Endocrinology 9, 1452-1562.

Carraway, R. E. and S. E. Leeman (1976). Characterization of radioimmunoassayable neurotensin in the rat. J. Biol. Chem. 251, 7045-7052.

Dismukes, K., M. Rogers and J. W. Daly (1976). Cyclic adenosine $3^{\prime}, 5^{\prime}$-monophosphate formation in guinea-pig brain slices; Effect of $\mathrm{H}_{1}$-and $\mathrm{H}_{2}$ histaminergic agonists. J. Neurochem. 26, 785-790.

Dolais-Kitabgi, J., P. Kitabgi, P. Brazeau and P. Freychet (1979). Effects of neurotensin on insulin, glucagon and somatostain release from isolated pancreatic islets. Endocrinology 105, 256-260.

Feldman, M. and C. T. Richardson (1978). Histamine $\mathrm{H}_{2}$-receptor antagonists. Adv. Int. Med. 23, $1-24$.

Green, J. P. (1964). Histamine and the central nervous system. Fed. Proc. 23, 1095-1102.

Green, M. D., B. Cox and P. Lomax (1976). Sites and mechanisms of action of histamine in the central thermoregulatory pathways of the rat. Neuropharmacology 15, 321-324.

Itatsu, T., A. Shibata and M. Ukai (1979). Effects of histamine receptor antagonists on neurotensininduced glucagon release from isolated pancreatic islets. Folia Endocrinol. Jpn. 55, 463 (Abstract, in Japanese).

Kaneto, A., T. Kaneko, H. Kajinuma and K. Kosaka (1978). Effects of substance $P$ and neurotensin infused intrapancreatically on glucagon and insulin secretion. Endocrinology 102, 393-401.

Kitabgi, P., R. E. Carraway and S. E. Leeman (1976). Isolation of tridecapeptide from bovine intestinal tissue and its partial characterization as neurotensin. $J \cdot$ Biol. Chem. 251, 7053-7058.

Lacy, P. E. and H. Kostianovsky (1967). Method for the isolation of intact islets of Langerhans from the rat pancreas. Diabetes 16, 35-39.

Lazarus, L. H., M. R. Brown and M. H. Perrin (1977). Distribution, localization and characteristics of neurotensin binding sites in the rat brain. Neuropharmacology. 16, 625-629.

Livertun, C. and S. M. McCann (1976). The possible role of histamine in the control of prolactin and gonadotropin release. Neuroendocrinology 20, 110-120.

Moltz, J. H., R. E. Dobbs, S. M. McCann and C. P. Fawcett (1977). Effects of hypothalamic factors on insulin and glucagon release from the islets of Langerhans. Endocrinology 101, 196-202.

Nagai, K. and L. A. Frohman (1976). Hyperglycemia and hyperglucagonemia following neurotensin administration. Life Sci. 19, 273-280.
Nagai, K. and L. A. Frohman (1978). Neurotensin hyperglycemia: Evidence for histamine mediation and the assessment of a possible physiologic role. Diabetes 27, 577-582.

Pontiroli, A. E., P. Micossi and R. P. Foa (1978). Effects of histamine, of histidine and of anti-histamine agents agents on the release of gluaagon and insulin from the rat pancreas. Horm. Metab. Res. 11, 100-103.

Rioux, F., M. A. Quirion, D. Leblanc, D. Regoli and S. St-Pierre (1980). Possible interactions between neurotensin and prostaglandins in the isolated rat portal vein. Life Sci. 27, 259-267.

Rivier, F., M. Brown and W. Vale (1977). Effects of neurotensin, substance $P$ and morphine sulfate on the secretion of prolactin and growth hormone in the rat. Endocrinology 100, 751-754.

Sasaki, H., Y. Yahata, K. Yamatani, M. Tominaga, I. Ebitani, H. Andoh, T. Katagiri and M. Hara (1980). Study about neurotensin-induced hyperglycemia. J. Jpn. Soc. Int. Med. 69, 213 (in Japanese).

Shaw, G. G. (1971). Hypothermia produced in mice by histamine acting on the central nervous system. Br. J. Pharmacol. 42, 205-214.

Shibata, A., T. Itatsu and M. Ukai (1978). Effects of neurotensin on glucagon release from isolated rat islets. 26th Annual Meeting, Western Section of the Japan Endocrine Society, p. 153 (Abstract, in Japanese).

Shibata, A., T. Itatsu and M. Ukai (1980). A Study of neurotensin effects on the endocrine pancreas using high glucose medium for preincubation of isolated islets. Igaku no Ayumi 114, 225-227 (in Japanese).

Ukai, M. and T. Itatsu (1976). Effects of vasopressin and neurotensin on hepatic glycogenolysis and the release of pancreatic hormones. 5th International Congress of Endocrinology, Hamburg, p. 217 (Abstract).

Ukai, M., I, Inoue and T. Itatsu (1977). Effects of somatostain on neurotensin-induced glucagon release and hyperglycemia. Endocrinology 100, 12841286.

Ukai, M., T. Itatsu and A. Shibata (1980). Effects of histamine receptor antagonists on glucagon release from isolated pancreatic islets by neurotensin and substance P. 6th International Congress of Endocrinology, Melbourne, p. 463 (Abstract).

Wide, L. and J. Porath (1966). Radioimmunoassay of proteins with the use of sephadex-coupled antibodies. Biochim. Biophys. Acta 130, 257-260. 